\title{
RANCANG BANGUN APLIKASI PRESENSI SISWA UNTUK MENGIDENTIFIKASI KEHADIRAN SISWA DI LINGKUNGAN SEKOLAH BERBASIS ANDROID DAN GPS
}

\author{
Yudi Herdiana, Rustiyana \\ Universitas Bale Bandung (UNIBBA) \\ E-mail: ydherdn@gmail.com; rustiyana@gmail.com
}

\begin{abstract}
Abstrak : Kehadiran siswa dalam lingkungan sekolah merupakan hal yang sangat penting diketahui, selain untuk presensi dalam pembelajaran, juga memastikan sekolah terhadap orangtua bahwa anaknya benar benar berada di lingkungan sekolah pada waktu yang sudah ditentukan. Saat ini di Sekolah masih menggunakan berkas untuk melakukan presensi siswa, dan hal tersebut sering bermasalah dengan tidak bisa dipastikan bahwa siswa berada di lokasi sekolah, presensi yang dimungkinkan hilang sehingga mengakibatkan kesalahan pada saat rekapitulasi presensi dan belum adanya aplikasi berbasis web sebagai layanan informasi presensi untuk orang tua siswa. Metodologi dalam rancang bangun aplikasi ini menggunakan metode Waterfall yang meliputi analisis, perancangan, pembuatan kode, pengujian, implementasi dan perawatan pada aplikasi dalam waktu tertentu, sedangkan untuk alat yang digunakan adalah Dreamweaver 8.0 untuk Editor dan Layout dan Android Studio untuk menyusun kode program. Aplikasi presensi siswa berbasis android dan gps merupakan aplikasi yang nantinya selain bisa menginformasikan presensi siswa juga sekaligus memastikan posisi siswa saat presensi dilakukan, sehingga diharapkan siswa selain tercatat juga dipastikan berada di lingkungan sekolah.
\end{abstract}

Kata Kunci : Presensi, Waterfall, Android Studio, GPS, Web

\section{Pendahuluan}

Dalam administrasi sekolah, presensi siswa dilakukan agar para guru dapat mengetahui kehadiran para siswanya dalam kegiatan belajar mengajar yang akan dilaksanakan di sekolah. Sesuai dengan tata tertib sekolah pada umumnya, para siswa harus disiplin waktu dengan datang ke sekolah tepat pada waktunya sesuai ketentuan sekolah. Dengan dilakukan presesensi siswa, guru dapat mengetahui siswa mana yang sering tidak masuk sekolah maupun siswa yang rajin masuk sekolah. Saat ini, presensi di Sekolah belum memanfaatkan teknologi informasi dan masih menggunakan berkas berupa buku sebagai alat untuk presensi. Masalah yang sering muncul adalah guru kesulitan memastikan siswa yang di periksa kehadirannya benar-benar berada di lingkungan sekolah, berkas presensi yang hilang, sulitnya merekapitulasi kehadiran siswa, dan belum adanya akses informasi mengenai kehadiran siswa melalui internet untuk orang tua siswa.

Dalam penelitian ini akan dibuat rancang bangun aplikasi presensi siswa berbasis android dengan fitur Global Positioning System (GPS), dan aplikasi berbasis web sebagai layanan informasi sekolah untuk orang tua siswa. Melalui aplikasi ini diharapkan bisa membantu sekolah dan orang tua siswa dalam mengetahui kehadiran siswa secara cepat dan tepat serta memastikan informasi siswa bilamana siswa tersebut tidak benar-benar berada di lokasi sekolah. 
Tujuan dari penulisan ini adalah mengidentifikasi siswa melakukan presensi pada waktu yang ditentukan, mendeteksi lokasi siswa saat mereka melakukan presensi, dan merancang aplikasi untuk mendeteksi keberadaan siswa ditinjau dari presensi yang mereka lakukan, sehingga dapat diketahui status siswa tersebut berada di lokasi sekolah atau tidak.

\section{Tinjauan Pustaka}

Perkembangan teknologi yang begitu pesat sangat mempengaruhi perubahan pola hidup manusia.Teknologi yang semakin canggih menuntut manusia menciptakan alat-alat yang mempermudah pekerjaan manusia. Salah satunya adalah pencarian lokasi user. Pencarian lokasi user menggunakan GPS (Global Positioning System) menentukan letak lokasi user. (Jurnal SAINTIKOM, Vol.13, No.2, 2014). Telepon pintar sudah menjadi gaya hidup masyarakat saat ini. Selain untuk komunikasi, telepon pintar juga digunakan sebagai alat pencari informasi yang cepat serta bebas, tidak bergantung tempat dan waktu. Pencarian informasi berdasarkan posisi pengguna. Pencarian informasi tempat yang berdasarkan posisi dan waktu dapat dilakukan dengan menggunakan location based service. (Jurnal JIKA, Volume 4, Nomor 1, hal 1-5, ISSN:2089-6026).

\subsection{Presensi}

Presensi adalah suatu kegiatan yang bertujuan untuk mengetahui tingkat prestasi kehadiran serta tingkat kedisiplinan dari anggota dalam suatu instansi, insitusi atau perusahaan. Presensi merupakan alat yang menghitung kehadiran seseorang dalam suatu instansi, institusi atau perusahaan, maka dari itu sangat diperlukan.

\subsection{Android}

Android adalah sistem operasi yang berbasis linux untuk telepon seluler seperti telepon pintar dan kompute tablet. android menyediakan platform terbuka bagi para pengembang untuk menciptakan aplikasi mereka sendiri untuk digunakan oleh bermacam piranti lunak. (Wijaya, 2012:2). Arsitektur Android secara umum terdiri dari lapisan software, yaitu lapisan aplikasi, lapisan framework, android run-time sebagai lapisan perantara (middleware), serta kernel linux yang membungkus hardware dibawahnya.

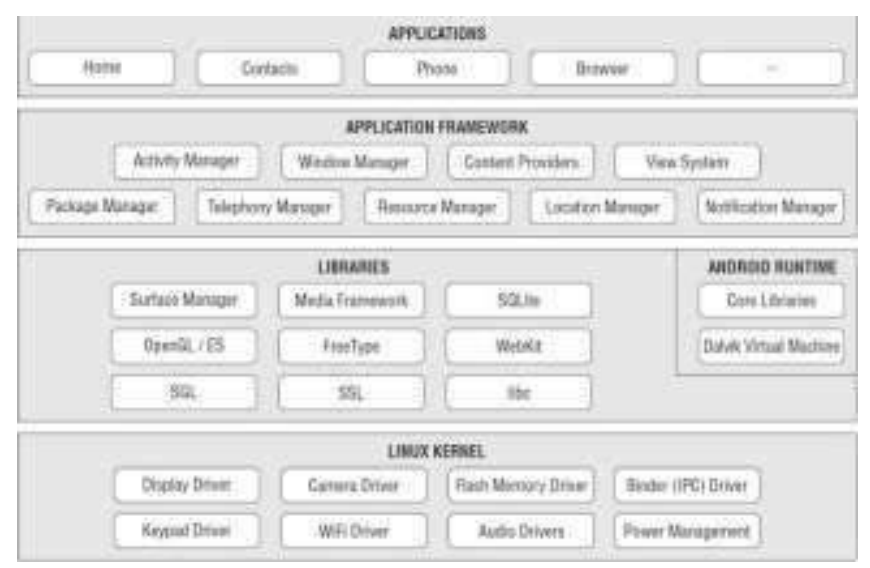

Gambar 1. Arsitektur Android (Sumber: Wei-Meng Lee Willey, Publishing) 
Komponen aplikasi Android ditulis dalam bahasa pemrograman Java, semua file kode intermidiate dan aset disatukan dalam stu paket file berekstensi .apk, sebuah file yang dapat didistribusi. Tiap file apk adalah sebuah aplikasi tunggal dengan komponen yang terdiri dari:

1. activity; istilah yang digunakan dalam pemrograman android untuk mengacu pada satuan interaksi dengan pengguna melalui antarmuka grafis.

2. intent; istilah yang digunakan dalam pemrograman android untuk mengacu pada mekanisme berbagai pesan pemberitahuan atau bertukar data activity atau untuk menjalan aplikasi lain.

3. service; komponen aplikasi yang berjalan di belakang layar tanpa user interface untuk menyediakan layanan tertentu seperti cek RSS feed secara kontinu atau memainkan musik. Service tetap berjalan meski activity yang mengendalikannya telah berhenti.

4. content provider; membuat suatu aplikasi dapat berbagi sejumlah data tententu kepada aplikasi lain.

5. broadcast receiver; komponen yang memantau, menerima, dan beraksi terhadap pesan yang disebarkan, baik oleh sistem maupun aplikasi lain.

\subsection{GPS}

Global Positioning System (GPS) menggunakan konstelasi dari 24 satelit yang mengelilingi bumi. GPS menemukan posisi pengguna dengan menghitung perbedaan waktu sinyal, dari setelit yang berbeda, untuk mencapai penerima.

Cara kerja GPS adalah sebagai berikut (Gambar 2.): Piranti GPS meminta data posisi koordinat satelit A saat ini dan data jarak piranti GPS terhadap satelit A. Lingkaran menyatakan posisi piranti GPS yang mungkin. Namun, masih terlalu banyak kemungkinan lokasinya. Piranti GPS meminta data posisi koordinat satelit B saat ini dan data jarak piranti GPS terhadap satelit B. Data dari satelit A dan B, keungkinan lokasi piranti GPS diturunkan hanya dua lokasi (kecuali jika lingkaran A dan B tetap bersinggungan, maka lokasi haya ada satu). Untuk menentukan lokasi yang benar, piranti GPS meminta data posisi koordinat satelit $\mathrm{C}$ saat ini dan data jarak piranti GPS terhadap satelit C. Dari data ketiga satelit tersebut dapat ditentukan posisi pasti piranti GPS.

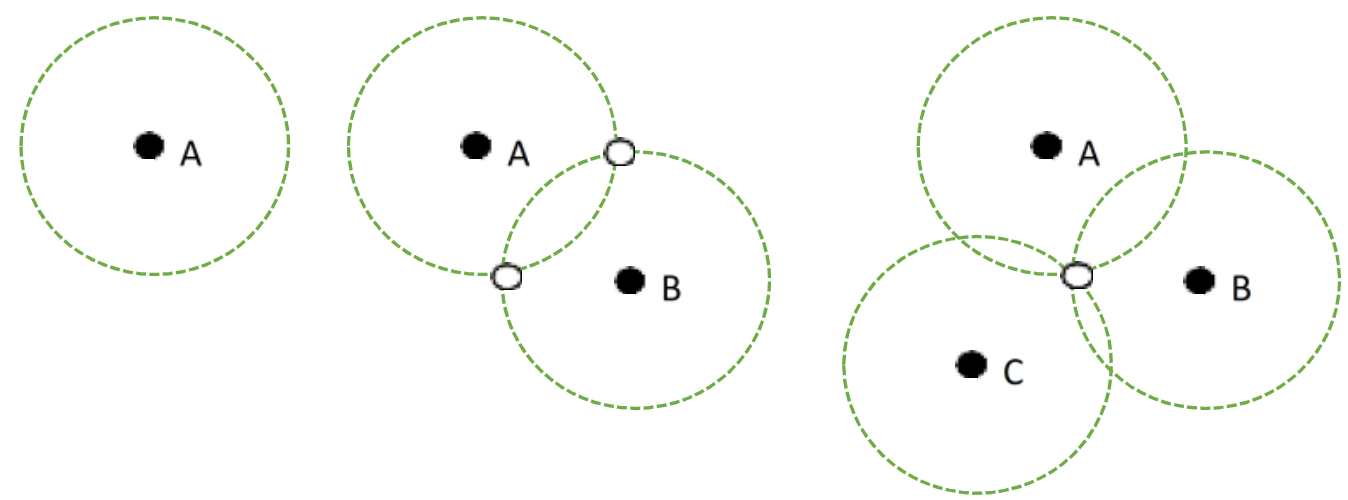

Gambar 2. Cara Kerja GPS

(Sumber: Juhara, 2016:208-209) 


\subsection{SDLC Waterfall}

Menurut Rosa A.S dan Shalahuddin (2015:26), SDLC atau Software Development Life Cycle atau sering disebut juga System Development Life Cycle adalah proses mengembangkan atau mengubah suatu sistem perangkat lunak dengan menggunakan model-model dan metodologi yang digunakan orang untuk mengembangkan perangkat sistem-sistem perangkat lunak sebelumnya (berdasarkan best practice).

Metode SDLC Waterfall (Air Terjun) menyediakan pendekatan alur hidup perangkat lunak secara sekuensial atau terurut dimulai dari analisis, desain, pengodean, pengujian, dan tahap pendukung (support).

Kelebihan model air terjun ini adalah sangat cocok digunakan ketika kebutuhan pelanggan sudah sangat dipahami dan kemungkinan terjadinya perubahan kebutuhan selama pengembangan perangkat lunak kecil, struktur tahap pengembangan sistem jelas, dokumentasi dihasilkan di setiap tahap pengembangan dan sebuah tahap dijalankan setelah tahap sebelumnya selesai dijalankan. Tahapan tersebut digambarkan pada Gambar 3 .

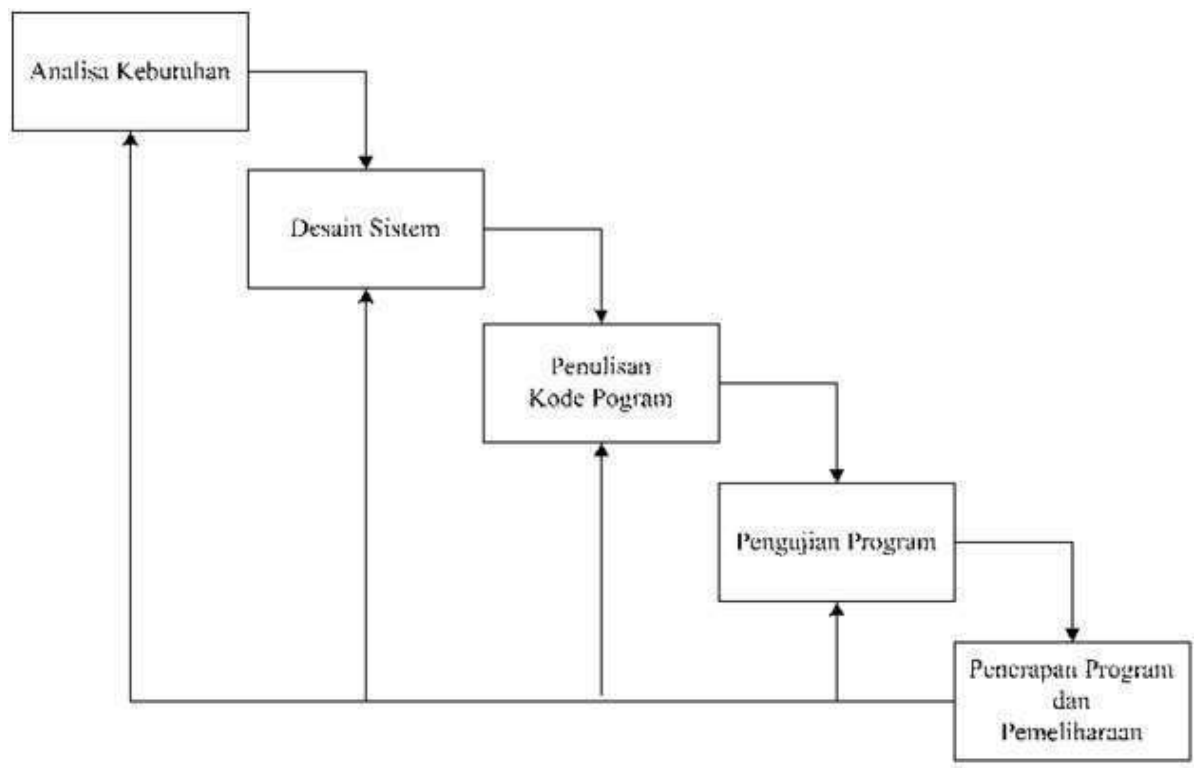

Gambar 3. SDLC Waterfall

(Sumber: Rosa A.S dan Shalahuddin,20015:26)

Tahapan-tahapan yang dilakukan pada model Waterfall adalah sebagai berikut:

1. Analisis kebutuhan perangkat lunak yaitu proses pengumpulan kebutuhan yang dilakukan secara intensif untuk menspesifikasikan kebutuhan perangkat lunak agar dapat dipahami perangkat lunak seperti apa yang dibutuhkan oleh user.

2. Desain yaitu proses multi langkah yang fokus pada desain pembuatan program perangkat lunak termasuk struktur data, arsitektur perangkat lunak, representasi antarmuka, dan prosedur pengkodean.

3. Coding yaitu proses mengokodean dari hasil desain yang ditranslasikan ke dalam bahasa pemrograman perangkat lunak. 
4. Pengujian yaitu proses pengujian yang berfokus pada perangkat lunak dari segi logic dan fungsional dan memastikan bahwa semua bagian sudah di uji untuk meminimalisir kesalahan (error) dan memastikan keluaran yang dihasilkan sesuai dengan yang diinginkan.

5. Pemeliharaan yaitu proses yang dilakukan setelah perangkat lunak digunakan oleh pengguna. Tidak menutup kemungkinan sebuah perangkat lunak mengalami perubahan ketika sudah digunakan oleh user, perubahan bisa terjadi karena adanya kesalahan yang muncul dan tidak terdeteksi saat pengujian atau perangkat lunak harus beradaptasi dengan lingkungan baru.

\subsection{Unified Modelling Language (UML)}

Menurut Rosa A.S. dan Shalahuddin (2015: 133), UML (Unified Modeling Language) adalah salah satu standar bahasa yang banyak digunakan di dunia industri untuk mendefinisikan requirement, membuat analisis dan desain, serta menggambarkan arsitektur dalam pemrograman berorientasi objek.

UML terdiri dari:

\section{Use Case Diagram}

Use Case Diagram mendeskripsikan sebuah interaksi antara satu atau lebih aktor dengan sistem informasi akan dibuat.

Tabel 1. Notasi Use Case Diagram

\begin{tabular}{|l|l|}
\hline Simbol & Deskripsi \\
\hline Use Case & $\begin{array}{l}\text { Fungsionalitas yang disediakan sistem } \\
\text { sebagai unit-unit yang saling bertukar } \\
\text { pesan antar unit atau aktor. }\end{array}$ \\
\hline Aktor / actor & $\begin{array}{l}\text { Orang, proses, atau sistem lain yang } \\
\text { berinteraksi dengan sistem informasi } \\
\text { yang akan dibuat di luar sistem } \\
\text { informasi yang akan dibuat itu sendiri. }\end{array}$ \\
\hline Asosiasi / association & $\begin{array}{l}\text { Komunikasi antara aktor dan use case } \\
\text { yang berpartisipasi pada use case atau } \\
\text { use case memiliki interaksi dengan } \\
\text { aktor. }\end{array}$ \\
\hline Eksteni / extend & $\begin{array}{l}\text { Relasi use case tambahan ke sebuah use } \\
\text { case dimana use case yang } \\
\text { ditambahkan dapat berdiri sendiri } \\
\text { walau tanpa use case tambahan itu. }\end{array}$ \\
\hline Generalisasi / generalization & $\begin{array}{l}\text { Hubungan generalisasi dan spesialisasi } \\
\text { (umum - khusus) antara dua buah use } \\
\text { case dimana fungsi yang satu adalah } \\
\text { fungsi yang lebih umum dari lainnya }\end{array}$ \\
\hline Menggunakan / include / uses & $\begin{array}{l}\text { Relasi use case tambahan ke sebuah use } \\
\text { case dimana use case yang }\end{array}$ \\
\hline
\end{tabular}




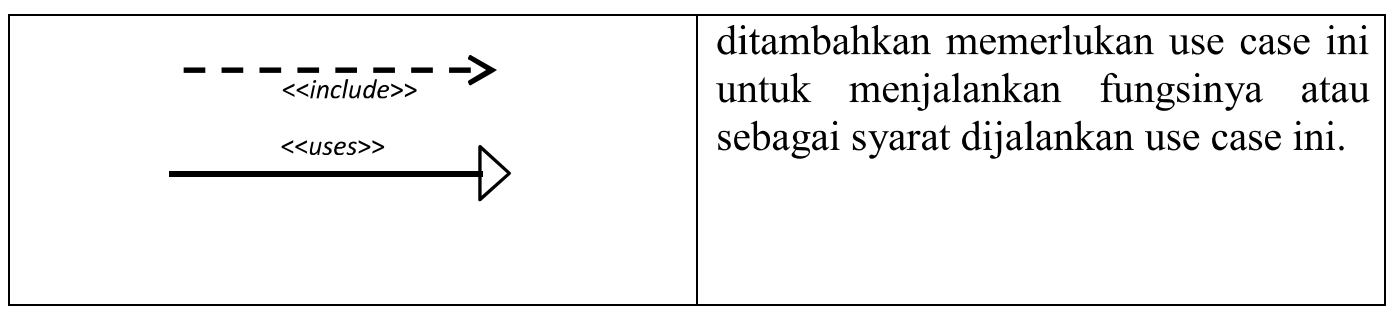

\section{Class Diagram}

Class Diagram menggambarkan struktur sistem dari segi pendefinisian kelas-kelas yang akan dibuat untuk membangun sistem.

Tabel 2. Notasi Class Diagram

\begin{tabular}{|c|c|}
\hline & Deskripsi \\
\hline Kelas / Class & \multirow[t]{4}{*}{ Class pada struktur system } \\
\hline nama_kelas & \\
\hline +atribut & \\
\hline +operasi() & \\
\hline Antarmuka / interface & $\begin{array}{l}\text { Sama dengan konsep interface dalam } \\
\text { pemrograman berorientasi objek. }\end{array}$ \\
\hline Asosiasi / association & $\begin{array}{l}\text { Relasi antarkelas dengan makna umum, } \\
\text { asosiasi biasanya juga disertai dengan } \\
\text { multiplicity. }\end{array}$ \\
\hline Assassin berarah / directed association & $\begin{array}{l}\text { Relasi antarkelas dengan makna kelas } \\
\text { yang satu digunakan oleh kelas lain, } \\
\text { asosiasi biasanya juga disertai dengan } \\
\text { multiplicity }\end{array}$ \\
\hline Generalisasi & $\begin{array}{l}\text { Relasi antarkelas dengan makna } \\
\text { generalisasi-spesialisasi } \\
\text { khusus) }\end{array}$ \\
\hline Kebergantungan / dependency & $\begin{array}{l}\text { Relasi antarkelas dengan makna } \\
\text { kebergantungan antarkelas. }\end{array}$ \\
\hline Agregasi / aggregation & $\begin{array}{l}\text { Relasi antarkelas dengan makna semua } \\
\text { bagian (whole-part) }\end{array}$ \\
\hline
\end{tabular}

\section{Activity Diagram}

Activity Diagram menggambarkan workflow (aliran kerja) atau aktivitas dari sebuah sistem atau proses bisnis atau menu yang ada pada perangkat lunak. 
Tabel 3. Notasi Activity Diagram

\begin{tabular}{|c|c|c|}
\hline Simbol & & Deskripsi \\
\hline Status awal & & $\begin{array}{l}\text { Status awal aktivitas system, sebuah } \\
\text { diagram aktivitas memiliki sebuah } \\
\text { status awal }\end{array}$ \\
\hline Aktivitas & aktivitas & $\begin{array}{l}\text { Aktivitas yang dilakukan system, } \\
\text { aktivitas biasanya diawali dengan kata } \\
\text { kerja }\end{array}$ \\
\hline Percabangan & decision & $\begin{array}{l}\text { Asosiasi percabangan dimana jika ada } \\
\text { pilihan aktivitas lebih dari satu }\end{array}$ \\
\hline Penggabung & $\mathrm{n} /$ join & $\begin{array}{l}\text { Asosiasi penggabungan dimana lebih } \\
\text { dari satu aktivitas digabungkan menjadi } \\
\text { satu }\end{array}$ \\
\hline Status akhir & & $\begin{array}{l}\text { Status akhir yang dilakukan sistem, } \\
\text { sebuah diagram aktivitas memiliki } \\
\text { sebuah status akhir }\end{array}$ \\
\hline Swimlane & nama swimlane & $\begin{array}{l}\text { Memisahkan organisasi bisnis yang } \\
\text { bertanggungjawab terhadap aktivitas } \\
\text { yang terjadi }\end{array}$ \\
\hline 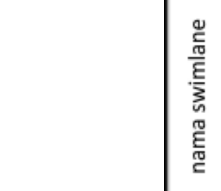 & & \\
\hline
\end{tabular}

\subsection{Database}

Database (Basis Data) adalah sistem terkomputerisasi yang tujuan utamanya adalah memelihara data yang sudah diolah atau informasi dan membuat informasi tersedia saat dibutuhkan. Pada intinya basis data adalah media untuk menyimpan data agar dapat diakses dengan mudah dan cepat (Rosa A.S dan Shalahuddin (2015:43).

Sedangkan menurut Arief (Setiawan, 2011: 4), Basis data merupakan sekumpulan data yang saling terintegrasi satu sama lain dan terorganisasi berdasarkan sebuah skema atau struktur tertentu dan tersimpan pada sebuah hardware komputer. Basis Data terdiri dari 
beberapa tabel (lebih dari satu tabel) yang saling terorganisir. Tabel digunakan untuk menyimpan data dan terdiri baris dan kolom. Data tersebut dapat ditampilkan, dimodifikasi, dan dihapus dari tabel. Setiap pemakai (user) yang diberi wewenang (otoritas) saja yang dapat melakukan akses terhadap data tersebut.

Basis data memiliki operasi dasar, yaitu:

1. Pembuatan basis data (create database)

2. Penghapusan basis data (drop database)

3. Pembuatan file atau table (create table)

4. Penghapusan file atau table (drop table)

5. Penambahan atau pengisian data baru (insert)

6. Pengambilan data (retrieve atau search)

7. Pengubahan data (update)

8. Pengapusan data (delete)

\subsection{Database Management System (DBMS)}

Menurut Oetomo (Tulangow, 2011: 38), DBMS adalah sistem database tempat penyimpanan data yang datanya harus saling berhubungan dan memiliki relasi dengan yang lain, misalnya Oracle dan SQL Server. DBMS adalah gudang data dari sistem. Kumpulan file yang tidak saling terkait satu sama lain tidak dapat disebut database.

Sedangkan menurut Rosa A.S dan Shalahuddin (2015: 44 - 45), DBMS (Database Management System) adalah suatu sistem aplikasi yang digunakan untuk menyimpan, mengelola, dan menampilkan data. Suatu sistem disebut DBMS jika memenuhi persyaratan minimal sebagai berikut:

1. Menyediakan fasilitas untuk mengelola akses data.

2. Mampu menangani integritas data.

3. Mampu menangani akses data yang dilakukan secara bersamaan.

4. Mampu menangani backup data.

\subsection{Web Service}

Menurut Wijaya (2012: 2), web service adalah sistem software yang dirancang untuk mendukung interopabilitas mesin ke mesin yang dapat berinteraksi melalui jaringan.

Sedangkan menurut Hartono dkk. (2013: 23), web service diartikan sebagai sebuah antar muka (interface) yang menggambarkan sekumpulan operasi-operasi yang dapat diakses dengan melalui jaringan, misalnya internet dalam bentuk pesan XML (eXtensible Markup Language).

Web service adalah suatu aplikasi yang mendeskripsikan sekumpulan informasi yang dapat diakses dalam sebuah jaringan melalui pesan yang telah distandarkan.(Taqwa, 2011: 11)

\section{Hypertext Markup Language (HTML)}

Menurut Sibero (2013: 19), HTML (HyperText Markup Language) adalah bahasa yang digunakan pada dokumen web sebagai bahasa pertukaran dokumen web. Struktur dokumen HTML terdiri dari tag pembuka dan tag penutup. 


\section{Extensible Markup Language (XML)}

Menurut Sibero (2013: 145), XML (eXtensible Markup Language) adalah suatu bahasa markup yang banyak digunakan sebagai media standar dalam pertukaran data.

\section{Java}

Menurut Wijaya (2012: 2), java adalah bahasa pemrograman yang dapat dijalankan di berbagai komputer termasuk telepon genggam. Java merupakan bahasa pemrograman yang bersifat umum/non-spesifik (general purpose), dan secara khusus didesain untuk memanfaatkan dependensi implementasi seminimal mungkin.

\section{PHP}

Menurut Hardianti dan Riasti (2013: 15), PHP adalah bahasa pemrograman untuk dijalankan melalui halaman web, umumnya digunakan untuk mengolah informasi di internet. Menurut Wijaya (2012: 2), PHP merupakan suatu bahasa pemrograman yang difungsikan untuk membangun suatu website dinamis

Sedangkan menurut Sibero (2013: 49), PHP adalah pemrograman interpreter yaitu proses penerjemahan baris kode sumber menjadi kode mesin yang dimengerti komputer secara langsung pada saat baris kode dijalankan. PHP disebut sebagai pemrograman Server Side Programming, hal ini dikarenakan seluruh prosesnya dijalankan pada server. Pemrograman PHP dapat ditulis dalam dua bentuk yaitu penulisan baris kode PHP pada file tunggal dan penulisan kode PHP pada halaman html (embedded)

\section{MySQL}

Menurut Sari (2014: 16), MySQL adalah sebuah program database server yang mampu menerima dan mengirimkan datanya dengan sangat cepat, multi user serta menggunakan perintah standar SQL (Structured Query Language).

Menurut Roziqin (2012: 5), MySQL merupakan turunan salah satu konsep utama dalam basis data yang telah ada sebelumnya yaitu SQL(Structured Query Language). MySQL mendukung operasi basis data transaksional maupun operasi basis data non-transaksional.

Sedangkan menurut Muna (2010: 2), MySQL adalah sebuah program database server, yaitu software database yang berbentuk database relasional atau dalam bahasa basis data biasa disebut Relation Database Management System (RDMS), yang mampu menerima dan mengirimkan datanya dengan sangat cepat, multi user serta menggunakan perintah standar SQL

\section{Javascript Object Notation (JSON)}

Menurut Sibero (2013: 148), JSON (Javascript Object Notation) adalah suatu bahasa markup yang dikembangkan sebagai bahasa standar dalam pertukaran data. Struktur JSON terbagi menjadi dua bagian, yaitu kumpulan struktur dengan nama dan nilai, yang juga disebut sebagai objek dan struktur dengan kumpulan objek yang membentuk suatu array. Menurut Wijaya (2012: 2), JSON merupakan format penulisan untuk pertukaran data seperti XML. JSON mampu melakukan pemindahan data antara dua interface dengan sangat cepat dan powerfull. 


\section{Internet}

Menurut Sutarman (Hapsari, 2010: 49), internet adalah sebuah solusi jaringan yang dapat menghubungkan beberapa jaringan lokal yang ada pada suatu daerah, kota atau bahkan pada sebuah Negara. Tidak hanya itu, dengan adanya fasilitas internet setiap orang dapat melakukan kegiatan mengirim email, cari data, atau bahkan belanja secara online

\section{Metodologi Penelitian}

Presensi siswa yang ada sebelumya dianalisis untuk mengetahui gambaran umum mengenai prosedur presensi siswa yang dilakukan, yang selanjutnya menganalisis kebutuhan aplikasi yang akan di buat berdasarkan data yang telah diperoleh dalam pengumpulan data untuk dijadikan landasan dalam perancangan aplikasi yang akan dibangun. Selanjutnya rancangan aplikasi dibuat meliputi konsep dasar, basis data, interface dengan memperhatikan kemudahan penggunaan aplikasi dan tampilan aplikasi. Setelah rancangan disetujui berikutnya dilakukan kodifikasi dengan menggunakan software dreamweaver dan android studio.

Untuk pengujian dan implementasi aplikasi dijalankan pada web server yang bisa diakses secara remote dan memastikan aplikasi sesuai dengan rancangan kebutuhan presensi dan bisa mendeteksi lokasi presensi menggunakan GPS, dan sekaligus melakukan perawatan aplikasi jika ditemukan bug atau error saat dilakukan implementasi.

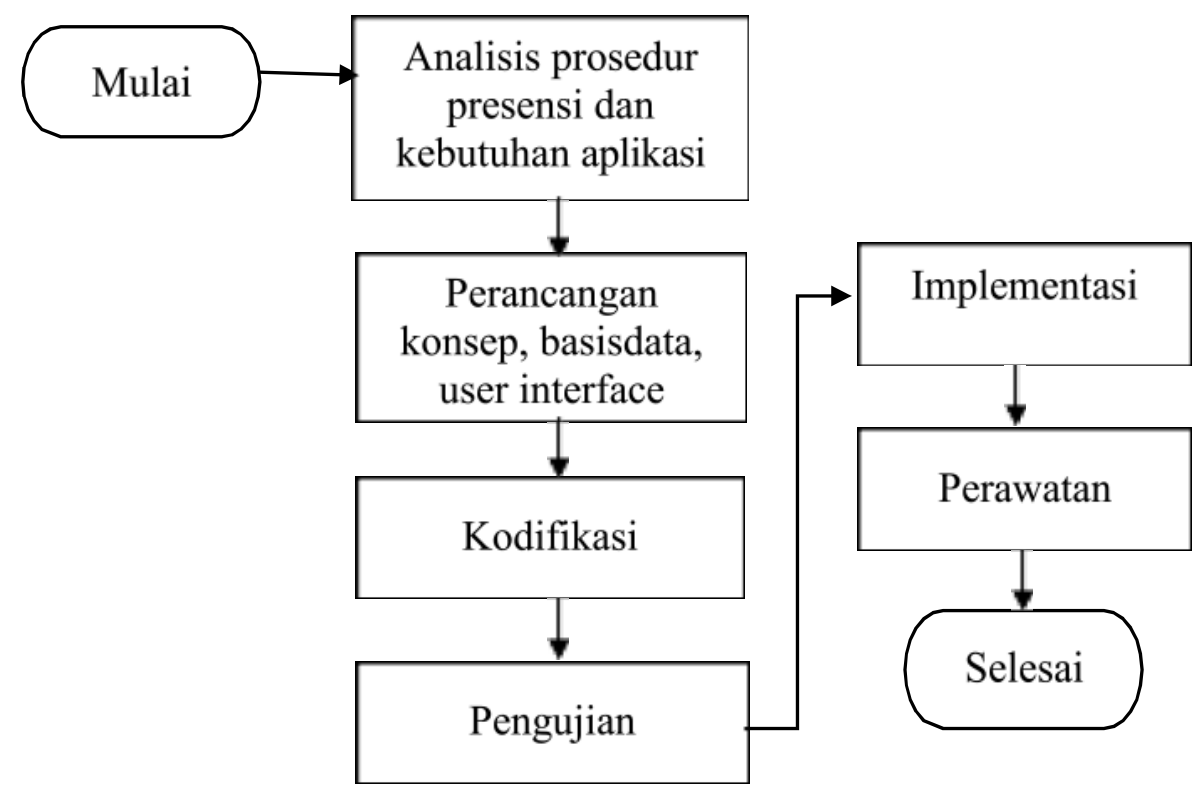

Gambar 4. Metodologi Penelitian

Teknik pengumpulan data yang dilakukan pada penelitian ini dilakukan dengan cara observasi/survey pada lokasi objek penelitian, studi pustaka yang sesuai dengan penelitian dan wawancara yang dilakukan pada pihak administrasi sekolah.

\section{Analisis Data}

a. Identifikasi Data 
Identifikasi data merupakan tahap awal dalam proses pemodelan aplikasi melalui langkah sebagai berikut:

1) Identifikasi sistem presensi siswa

Sistem presensi siswa yang akan dirancang disesuaikan dengan prosedur yang berlaku di sekolah.

2) Identifikasi bentuk data (database)

Dikarenakan sistem yang akan dibangun berbasis android dan komunikasi data dilakukan menggunakan jaringan internet maka bentuk data yang ada akan disesuaikan dengan arsitektur data berbasis android.

b. Identifikasi data pengguna yang menggunakan perangkat mobile jenis smartphone.

c. Penggunaan aplikasi untuk mendesain tampilan untuk data.

d. Bahasa pemrograman yang akan digunakan dalam melakukan kodifikasi desain aplikasi dan transaksi data.

Pelaksanaan penelitian saat ini sudah mencapai beberapa kemajuan atau progress diantaranya adalah : Survey, koordinasi dengan pihak terkait, pengumpulan data dan kompilasi data, penyediaan beberapa sarana dan referensi penelitian, dan sudah memasukan tahapan konsep desain.

Hasil sementara pada tahapan penelitian adalah konsep tahapan prosedur presensi, kebutuhan aplikasi, dan kebutuhan fungsional pada aplikasi yang akan dimodelkan, sebagai berikut:

\section{Pembahasan}

\section{Prosedur Presensi}

a. Siswa memasuki lingkungan sekolah.

b. Tanda masuk sekolah dibunyikan.

c. Seluruh siswa berada di dalam kelas.

d. Sekretaris mengambil buku presensi siswa.

e. Sekretaris memanggil dan melihat satu persatu siswa untuk memastikan kehadirannya dan mengisi kehadirannya di buku presensi siswa.

f. Apabila siswa tidak hadir maka sekretaris menanyakan kepada siswa lain apakah kehadiran siswa tersebut ijin, sakit, atau alpa (tanpa keterangan).

g. Jika siswa tersebut ijin atau sakit maka sekretaris akan menanyakan kembali apakah ada surat keterangan yang memberitahukan siswa tersebut ijin atau sakit.

h. Apabila surat keterangan ada maka keterangan siswa tersebut sesuai dengan kehadiran yang dituliskan dalam surat keterangan, apabila surat keterangan tidak ada maka siswa tersebut dianggap alpa (tanpa keterangan).

i. Staf kesiswaan mendatangi setiap kelas dan mendata kehadiran siswa perkelas berdasarkan buku presensi siswa ke dalam buku besar presensi siswa.

j. Staf kesiswaan merekap data presensi siswa di buku besar presensi siswa.

Berdasarkan prosedur diatas, peneliti menyimpulkan bahwa untuk melakukan pendataan kehadiran siswa oleh sekretaris membutuhkan waktu sekitar 10 detik persiswa dan apabila jumlah siswa maksimal 35 orang perkelas, maka akan membutuhkan waktu sekitar 6 menit dan untuk melakukan pendataan kehadiran oleh staf kesiswaan akan dibutuhkan waktu sekitar 3 menit perkelas sehingga waktu yang dibutuhkan akan 
bertambah apabila jumlah kelas bertambah, terlebih di sekolah memiliki beberapa jurusan.

\section{Kebutuhan Aplikasi}

Analisis kebutuhan aplikasi dilakukan untuk mendapatkan gambaran perancangan aplikasi yang akan dibangun, analisis ini bertujuan untuk mengetahui kebutuhan aplikasi. Kebutuhan aplikasi dapat di rumuskan dari hasil analisis pada sistem yang berjalan dan dari hasil pengumpulan data yang sudah dilakukan sebelumnya. Adapun analisis kebutuhan aplikasi yang dilakukan sebagai berikut:

1. Sebelum kegiatan belajar mengajar dilakukan, setiap guru akan melihat daftar kehadiran siswa di buku presensi siswa sehingga aplikasi diharuskan dapat diakses oleh setiap guru.

2. Administrasi sekolah pada presensi siswa masih menggunakan buku presensi sehingga orang tua harus menghubungi sekolah untuk memastikan kehadiran anaknya di sekolah. Oleh karena itu, aplikasi diharuskan dapat di akses juga oleh orang tua siswa.

3. Rekap siswa yang dibuat masih rentan terjadi kesalahan karena masih dilakukan dengan menghitungnya secara manual sehingga dapat terjadi kesalahan perhitungan terlebih apabila jumlah siswa yang banyak.

4. Sekitar $80 \%$ siswa memiliki smartphone android dengan rata-rata menggunakan sistem operasi android Jelly Bean dengan versi $4.1 \mathrm{ke}$ atas sehingga aplikasi yang akan dibuat minimal dapat digunakan dengan sistem operasi android Jelly Bean dengan versi 4.1 .

Staf kesiswaan (Admin) tidak menggunakan smartphone android tetapi diberikan fasilitas komputer dan laptop oleh sekolah sehingga aplikasi yang akan dibuat harus dapat diakses melalui komputer atau laptop.

\section{Kebutuhan fungsional}

Kebutuhan fungsional aplikasi presensi siswa sebagai berikut:

1. Login admin, wali kelas dan siswa, untuk memastikan hak akses yang diperoleh untuk admin, wali kelas dan siswa dengan memasukan username (admin dan wali kelas) atau nis (siswa) dan password.

2. Login umum pada apresis berbasis android tidak akan menggunakan username dan password.

3. Pengolahan data kehadiran siswa.

4. Menampilkan informasi kehadiran siswa pada hari itu.

5. Apresis memiliki fitur untuk mengelola data user.

6. Apresis memiliki fitur untuk mengelola data siswa.

7. Apresis memiliki fitur untuk mengelola data jurusan.

8. Apresis memiliki fitur untuk mengelola data semester.

9. Apresis memiliki fitur untuk mengelola data jam kelas.

10. Apresis memiliki fitur untuk mengelola data libur.

11. Apresis memiliki fitur untuk mengelola data kehadiran. 


\section{Rancangan Aplikasi}

\section{Use Case Diagram}

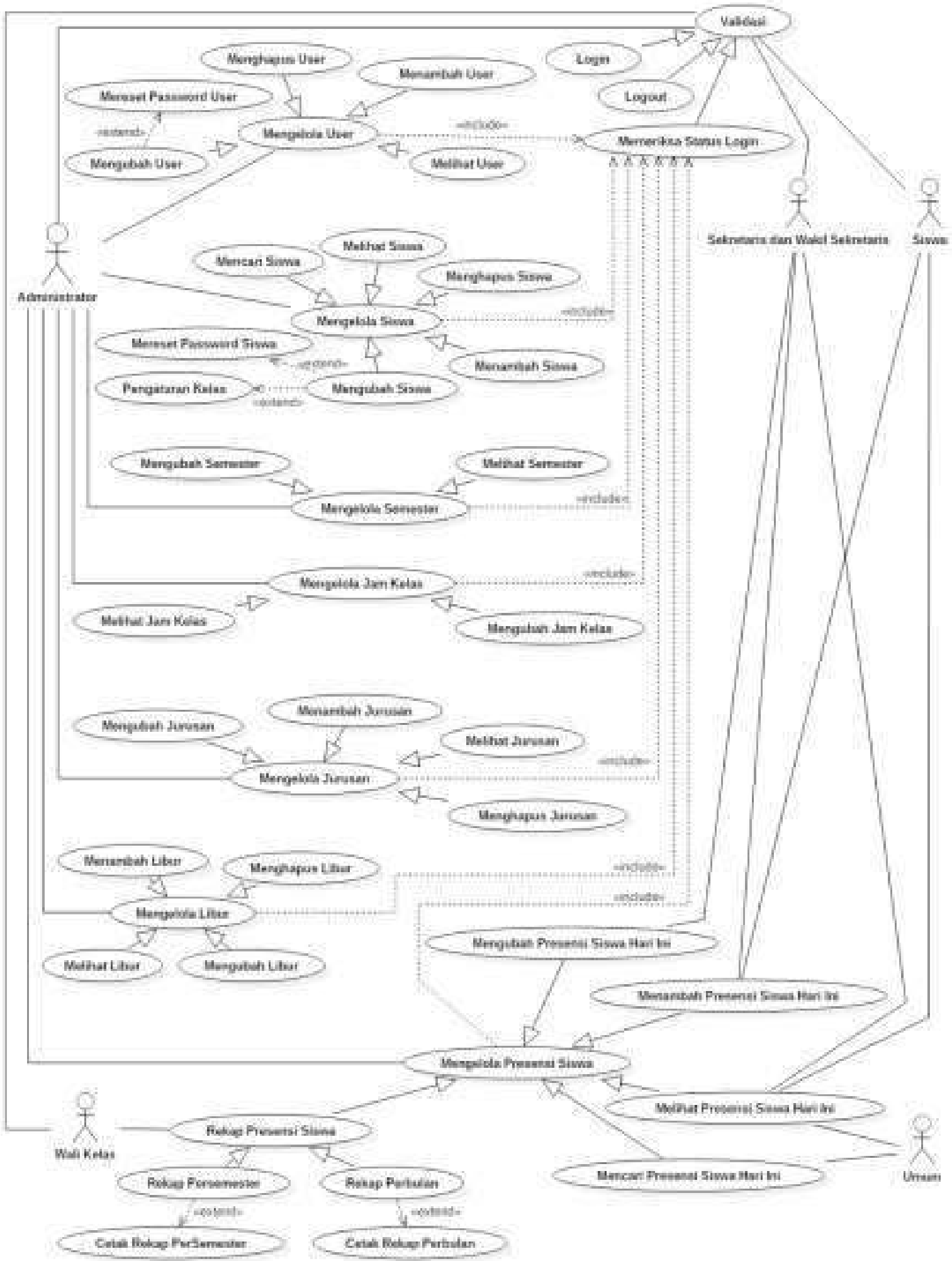




\section{Rancangan Class Diagram}

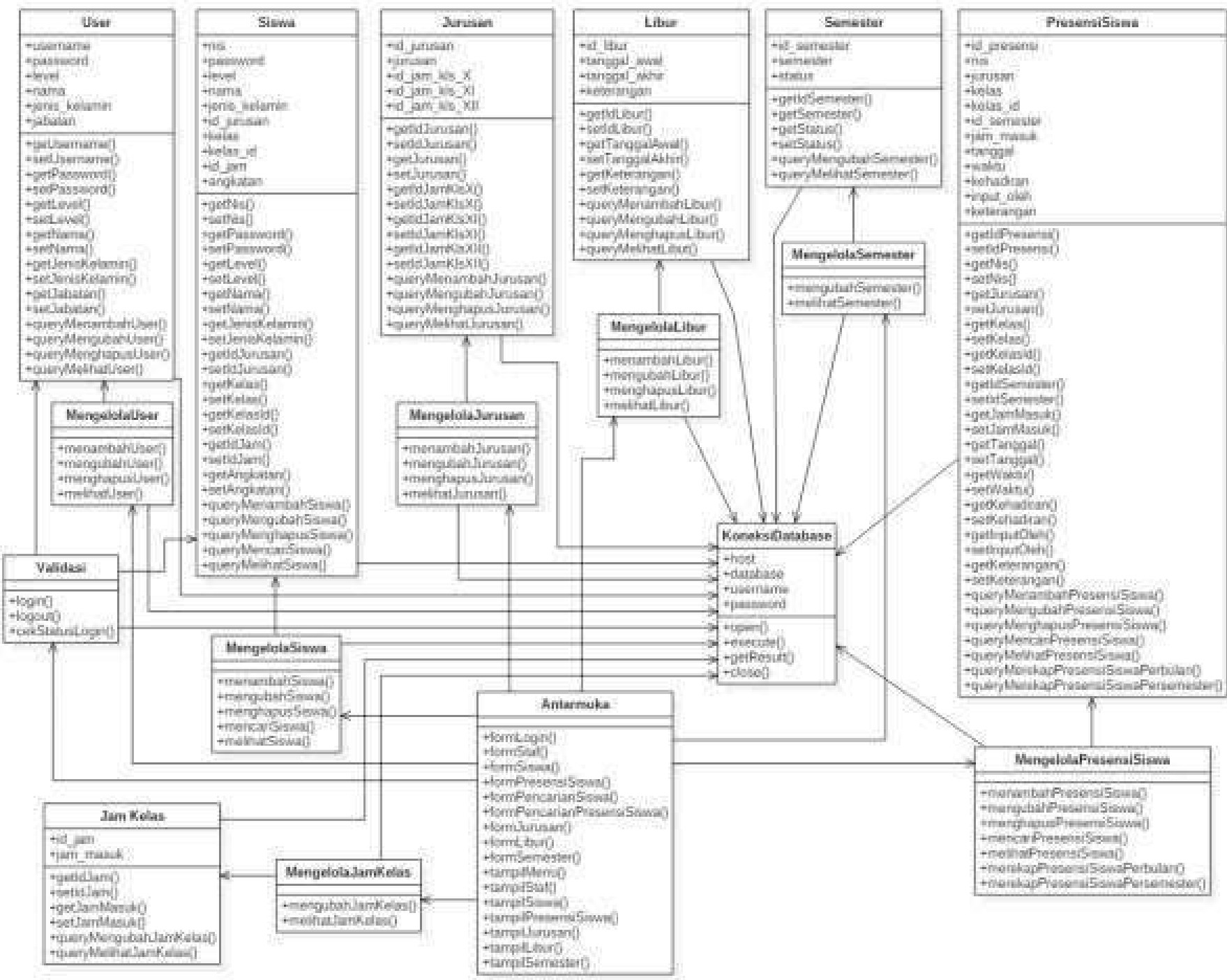

Tampilan Aplikasi pada Web

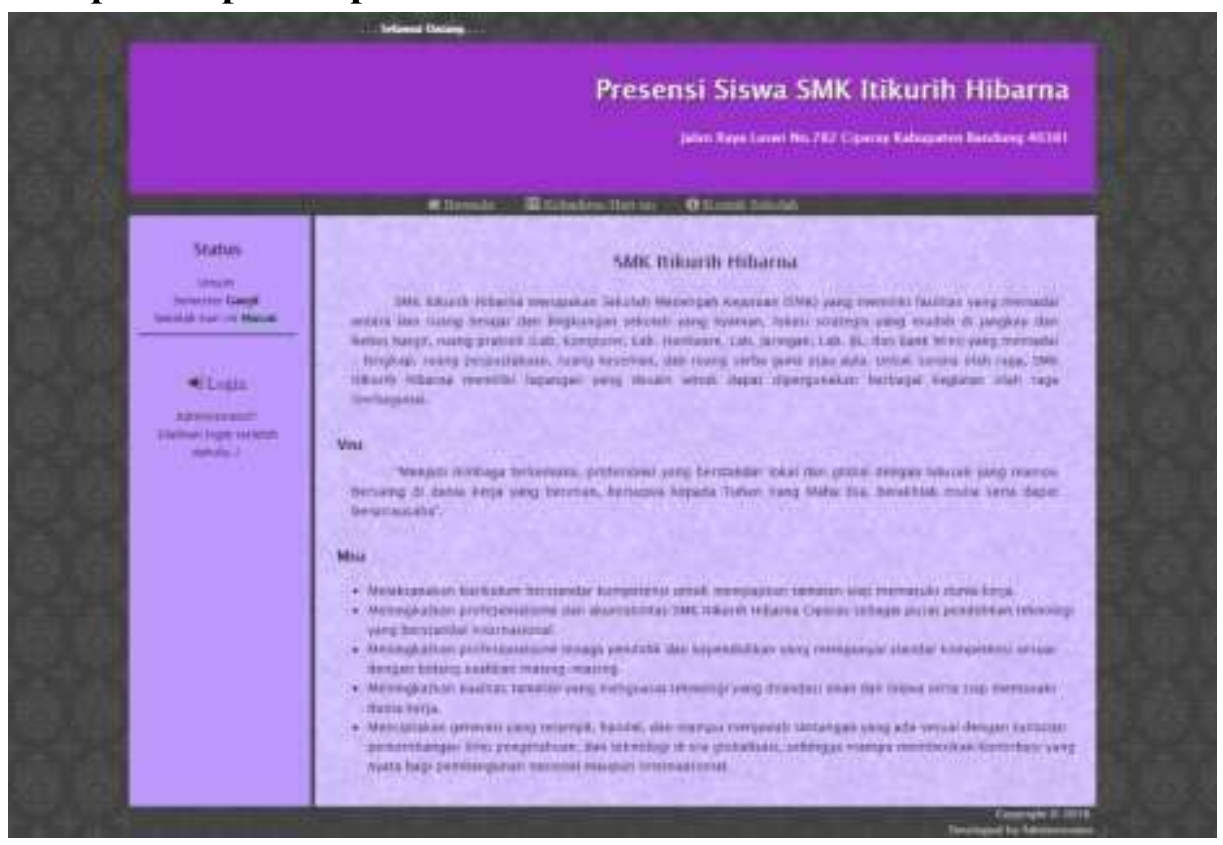


Tampilan Aplikasi pada Android
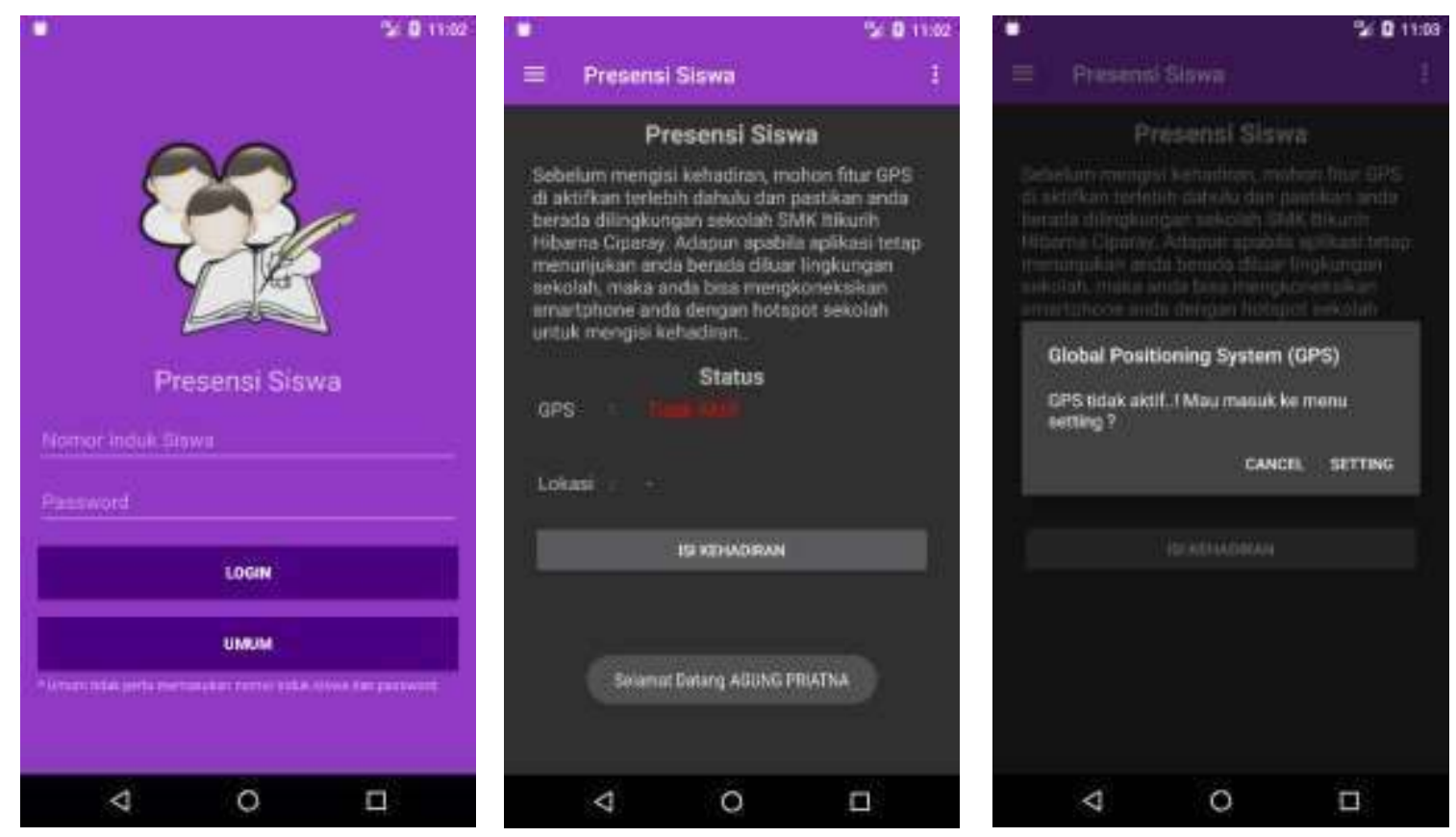

\section{Kesimpulan}

Berikut beberapa kesimpulan yang diperoleh dari hasil penelitian sampai dengan saat ini adalah:

1. Analisis Prosedur administrasi sekolah pada presensi siswa

2. Kebutuhan aplikasi yang akan dibuat berdasarkan pola sistem presensi yang ada

3. Kebutuhan fungsional pada aplikasi yang memungkinkan bisa menjadi layanan presensi

\section{Daftar Pustaka}

[1] Ahmad Fali Oklilas, Sri Desy Siswanti, M. Dieka Rachman, Akurasi Pembacaan GPS pada Android untuk Location Based Service (Studi Kasus: Informasi Lokasi SMA di Palembang), Jurnal JIKA, Volume 4, Nomor 1, hal 1-5, ISSN:2089-6026.

[2] Andi Juansyah, Pembangunan Aplikasi Child Tracker Berbasis Assisted-Global Positioning System (A-GPS) Dengan Platform Android, Jurnal KOMPUTA, Edisi 1, Volume 1, Agustus 2015, ISSN: 2089-9033.

[3] Badrul Andwar, Hendra Jaya, Putra Indra Kusuma. Implementasi Location Based Service Berbasis Android Untuk Mengetahui Posisi User, Jurnal SAINTIKOM, Vol.13, No. 2, Mei 2014, ISSN: 1978-6603.

[4] Foeng Hartono, Nina Sevani, Aplikasi Navigasi Lokasi POM Bensin di Jakarta Berbasis Android, Jurnal Teknik dan Ilmu Komputer, Vol. 02, No. 05, Jan-Mar 2013.

[5] Juhara, Z.P., (2013). Panduan Lengkap Pemrograman Android. Yogyakarta: CV. Andi Offeset.

[6] Rosa AS dan M.Shalahuddin. (2015). Rekayasa Perangkat Lunak Terstruktur Dan Berorientasi Objek. Bandung : INFORMATIKA. 
[7] Wijaya, I. W. (2012). Penerapan Web Service Pada Aplikasi Sistem Akademik Pada Plaftorm Sistem Operasi Mobile Android 2. 